\title{
An overview of cleaning and prevention processes for enhancing efficiency of solar photovoltaic panels
}

\author{
Surajit Mondal ${ }^{1}$, Amit Kumar Mondal ${ }^{2}$, Abhishek Sharma ${ }^{2}$, Vindhya Devalla ${ }^{3}$, \\ Sravendra Rana ${ }^{1}$, Suresh Kumar ${ }^{4}$ and Jitendra Kumar Pandey ${ }^{1, *}$ \\ ${ }^{1}$ Department of Research and Development, \\ ${ }^{2}$ Electronics, Instrumentation and Control Engineering, \\ ${ }^{3}$ Aerospace Engineering, and \\ ${ }^{4}$ Mechanical Engineering, University of Petroleum and Energy Studies, Dehradun 248 007, India
}

The energy produced by solar photovoltaic (SPV) modules is directly connected with the solar accessible irradiance, spectral content, different variables like environmental and climatic components. Dust and bird droppings are considered as the real challenges for SPV performance. This article covers dust-related challenges and advanced improvements made on the automated cleaning system, by providing a brief framework on strategies such as mechanical, electrical, chemical and electrostatic. The environmental impact of cleaning processes has also been evaluated, which is directly related to the ultimate performance of overall conversion.

Keywords: Automated cleaning process, dust, electrodynamic screening, particle removal, solar photovoltaics.

SOLAR energy is considered as the main solution for the energy demand of the world when non-renewable sources of energy are declining ${ }^{1}$. Solar-based energy systems are convenient due to their easy installation, maintenance and longer durability.

Utilization and conversion of solar energy is a complex photochemical process, requiring optimization of several parameters for an acceptable level of efficiency, where the process is directly controlled by surface characteristics and its cleaning. Solar photovoltaic (SPV) cleaning and prevention from dust are two main aspects of maintenance required for enhanced and longer yield. Other parameters such as increase in temperature, overheating ${ }^{2-4}$ and physical hindrance of sunlight may cause its scattering from the SPV surface resulting in low absorption ${ }^{5}$.

Although cleaning of solar panel has been a defining challenge for researchers mainly for balancing the cost with performance and durability, continuous efforts in this direction seem to be a positive step towards enhancing the efficiency of the devices. Dust is a fine, dry powder comprising miniature units of earth or waste

*For correspondence. (e-mail: jeetu_ncl@yahoo.com) material $^{6}$. Dust settlement for the most part depends on numerous components like compound properties, size, weight, shape, site, tilt point surface completion, stickiness, wind speed, etc. ${ }^{7-11}$. Dust exposure affects many parameters of SPV; so several attempts have been made to address this issue (Tables 1 and 2). However, there are a variety of approaches for cleaning depending on weather or on power generation capacity (Tables 3 and 4).

\section{Cleaning techniques}

There are several challenges and benefits related to the cleaning techniques. All the techniques are mainly focused on reducing the adhesion bond between dust particles and the panel by controlling electrostatic repulsion $(E R)^{12-18}$. This strategy is aimed at incorporating materials or system designs that use non-contact, continuous techniques which require little or no labour for cleaning.

\section{Electrostatic biasing}

This is mainly directed at SPV cleaning in space application. Apart from the traditional/conventional cleaning techniques, special ones are required for space related conditions. The process should be non-contact type, which reduces manpower. As the space environment (explored so far) is dry or non-humid, and since the dust particles are ionized due to lack of atmosphere around them, suitable techniques were applied earlier ${ }^{13-17,19-21}$. An electrostatic biasing film consists of rows of transparent, conducting, parallel electrodes sandwiched between two transparent dielectric layers. This film is integrated with SPV module on its optical surface to maintain high transmission efficiency without the need for water. To remove dust particles deposited on an electrostatic biasing film surface, the electrodes are activated by applying low-frequency, high-voltage pulses. The dust particles are then electrostatically charged and removed 
Table 1. Factors affecting the reaction to dust

\begin{tabular}{lr}
\hline Parameters & \multicolumn{1}{c}{ Details } \\
\hline $\begin{array}{l}\text { Frequency of dust settlement incidents } \\
\text { Generally a community is equipped to withstand an incident once a } \\
\text { month; however, the community needs to prepare for repetitive } \\
\text { incidents at frequencies of once or twice a week. }\end{array}$ \\
$\begin{array}{l}\text { Dust deposition has an inverse relationship with distance of the } \\
\text { dust source and is one of the major factors for determining the } \\
\text { level of complaint. }\end{array}$ \\
$\begin{array}{l}\text { If the emissions upsurge, then there is a probability for larger } \\
\text { area therefore will increase the probability of complaint. }\end{array}$ \\
\hline
\end{tabular}

by Coulomb force ${ }^{22}$. Electric field distribution and dust particles charge acquired during removal play an important role during the cleaning process and evaluation of electrostatic performance.

Standing wave: The electric curtains contain a series of parallel electrodes planted in a dielectric layer ${ }^{19}$. Providing AC voltage supply along one electrode and grounding the other electrode creates a unidirectional electric field, with amplitude oscillating at the imposed frequency. The charged particle oscillates along with the field line (Figure 1).

Ionized gas below the inception voltage shows intense agitation $^{23}$. This phenomenon in combination with tribocharging ${ }^{13}$ is used for removing dust from SPV surface by providing voltage supply (called dielectric barrier discharge voltage) less than the agitation voltage.

Multiphase electric curtain: Similar to the standing wave, to generate travelling nature of the wave at a direction normal to the electrode axes, three-phase supply including phase shifts of $2 \pi / 3$ and $4 \pi / 3$ has been provided to electrodes (non-uniform electric field distribution). Two types of force components act over the charged particles $^{24}$, which include an outward component along $O_{z}$ (normal to the plain of the curtain) and a component along $O_{x}$ (parallel to the plain of the curtain and normal to the axis of the electrodes). The resulting force (called dielectrophoretic (DEP) force $\mathrm{e}^{25,26}$ ) is relative to the particle charge, field, field gradient and frequency and help for lift to the charged particle to sweep of the field (Figure 2). Above mentioned technique of multiphase electric curtain is been used by Masuda et al. ${ }^{24}$ developed a layer of electric curtain which prevents the charged particles from reaching the SPV surface, and further lifting and transporting the charged particles.

The above-mentioned clearing of SPV surface using electrostatic biasing shows the following unique characteristics: (a) expulsion of dust is proportional to the applied voltage; (b) dust expulsion performance decreases with respect to applied pressure on the surface and (c) cleaning efficiency decreases with relative increase in humidity.
For removing dust from SPV surface under Martian environment, generally voltage in the range of $10 \mathrm{kV}$ and frequency range $10-100 \mathrm{~Hz}$ are required ${ }^{13}$. Mazumder et $a{ }^{27}$ and Bock et $a l^{28}$ used electrodynamic screens to patent technology for the Mars Rover. Biryukov et al. ${ }^{29}$ further developed the electrostatic biasing approach, including dielectrophoretic prototype device to attain a dust removal efficiency of $90 \%$. Clark et al. ${ }^{30}$ explored an electrostatic tool called 'SPARCLE' to deal with lunar dust, where an electron beam has been used to control the electrostatic potential.

Electrostatic repulsion (ER) techniques are innovative; however, cost competitiveness is still a key issue for their feasibility and commercialization.

\section{Autonomous cleaning techniques}

There are a few techniques accessible in industrial grade that could be utilized in real time through robots for cleaning, where the existing solutions are subject to geographical terrain, application area, cost of device, sophistication and performance ratio. On the basis of cost, ease of utilization, performance rate, water consumption, etc., robotic solutions have emerged as an attractive option for SPV surface cleaning.

Solar panel cleaning robot is a two-body structure for SPV module cleaning ${ }^{31}$. It comprises a mobile robot which carries the cleaning payload and cleaning head, which actually does the cleaning work. The cleaning head undergoes horizontal motion with the help of motorized trolleys at the edges of panels, while the belt-driven system attached directly with the cleaning head undergoes vertical motion. Cleaning head comprises rotating antiscratch cylindrical brushes to scrub the SPV surface and a scraper to remove the dirt solution (Figure 3).

Moreover, robotic cleaning mechanisms such as 'Gekko Solar', 32 and 'Gekko Solar Farm'33 (Serbot Swiss Innovations) developed for mobile deployment onto SPV (Figure 4) have shown good potential. The robot works through a revolving brush using demineralized water. Vaccum cup-based feet are used for its movement over the SPV panel, which in turn revolves on two 
REVIEW ARTICLES

Table 2. Summary of selected reports of dust effects on solar photovoltaic device performances ${ }^{10,11}$

\begin{tabular}{|c|c|c|c|c|}
\hline Location & $\begin{array}{l}\text { Type of } \\
\text { solar device }\end{array}$ & $\begin{array}{l}\text { Period } \\
\text { of study }\end{array}$ & Observations & Reference \\
\hline Boston, MA, USA & $\begin{array}{l}\text { Solar-thermal } \\
\text { collectors }\end{array}$ & 3 months & $\begin{array}{l}\text { Maximum degradation during the test period is } 4.7 \% \text {. } \\
\text { A correction factor of } 0.99 \text { (for a } 45^{\prime \prime} \text { tilt angle). }\end{array}$ & 10 \\
\hline New York, USA & Glass samples & 3 months & $\begin{array}{l}\text { At tilt angles between } 0^{\prime \prime} \text { and } 50 " \text {, the reduction in } \\
\text { solar radiation due to dirt is } 5 \% \text {. }\end{array}$ & 79 \\
\hline Cleveland, OH, USA & PV modules & 1 year & $\begin{array}{l}\text { Degradation is site-dependent. Washing does not eliminate all } \\
\text { degradation, permanent loss in maximum power reaches a steady } \\
\text { value after several hundred days. } \\
\text { Local condition is most damaging. }\end{array}$ & 80 \\
\hline $\begin{array}{l}\text { California and } \\
\text { south-western USA }\end{array}$ & $\begin{array}{l}\text { PV system } \\
\text { (grid-connected) }\end{array}$ & 1 year & $\begin{array}{l}\text { 'Soiling' study for utility-connected PV system. } \\
\text { Efficiency and energy losses (typical } 0.2 \% \text { per day without rainfall). }\end{array}$ & 81 \\
\hline Lexington, MA, USA & $\begin{array}{l}\text { PV module } \\
\text { (glass) }\end{array}$ & 18 months & $\begin{array}{l}\text { Measurement of soil accumulation and model cleaning } \\
\text { using gloss meter. }\end{array}$ & 82,83 \\
\hline Oregon, USA & $\begin{array}{l}\text { Solar module } \\
\text { array (glass) }\end{array}$ & 6 years & $\begin{array}{l}\text { Unwashed solar cell array degrades at the rate about } 1.4 \% \text { per year. } \\
\text { Fluctuations in degradation (rates) do exist and long-term testing } \\
\text { of degradation is needed. }\end{array}$ & 84 \\
\hline Saudi Arabia & Solar collectors & 25 days & Heat-collection reduction of $30 \%$ after three days without wiping. & 85 \\
\hline Saudi Arabia & $\begin{array}{l}\text { Concentrated } \\
\text { photovoltaic }\end{array}$ & 1 month & $\begin{array}{l}\text { Open-circuit voltage does not change, and short-circuit current } \\
\text { and cell efficiency show a large change with dust deposition. }\end{array}$ & 86,87 \\
\hline Saudi Arabia & $\begin{array}{l}\text { PV modules } \\
\text { (glass) }\end{array}$ & 6 months & $\begin{array}{l}33.5 \% \text { and } 65.8 \% \text { reductions in efficiency after one and six months } \\
\text { respectively. }\end{array}$ & 88 \\
\hline Saudi Arabia & $\begin{array}{l}\text { Solar collectors } \\
\text { and PV modules } \\
\text { (glass) }\end{array}$ & 6 months & $\begin{array}{l}26 \% \text { and } 40 \% \text { reduction of efficiency from solar collector and PV } \\
\text { panels respectively. }\end{array}$ & 89 \\
\hline Riyadh, Saudi Arabia & PV module (glass) & 1 year & $\begin{array}{l}\text { Efficiency decreases by } 5.73-19.8 \% \text { depending on the type of } \\
\text { module, when presented to the outside environment. } \\
\text { Compared Module specifications are compared with the } \\
\text { manufacturer's claims (differences). Hot, arid conditions. }\end{array}$ & 90 \\
\hline Saudi Arabia & $\begin{array}{l}\text { Solar collectors } \\
\text { and PV modules } \\
\text { (glass) }\end{array}$ & 1 year & $\begin{array}{l}7 \% \text { reduction per month for PV panels and } 2.8-7 \% \text { for } \\
\text { solar collectors. }\end{array}$ & 91 \\
\hline Kuwait & PV modules (glass) & 6 days & $17 \%$ reduction in the efficiency of modules. & 92 \\
\hline $\begin{array}{l}\text { Laboratory tests and } \\
\text { Kuwait }\end{array}$ & $\begin{array}{l}\text { Solar cells } \\
\text { (large-area) }\end{array}$ & 10 days & $\begin{array}{l}\text { Current losses of greater than } 13 \% \text { and voltage losses of } \\
\text { greater than } 0.86 \%(5-15 \% \text { loss in peak power }) \text {. }\end{array}$ & 93 \\
\hline Helwan, Cairo, Egypt & $\begin{array}{l}\text { PV cells } \\
\text { and glass }\end{array}$ & 7 months & $\begin{array}{l}\text { Decrease in PV output of about } 17.4 \% / \text { month. } \\
\text { Provides information as a function of tilt angle. }\end{array}$ & 94 \\
\hline Israel & $\begin{array}{l}\text { PV modules } \\
\text { (glass) }\end{array}$ & $\begin{array}{l}\text { Laboratory } \\
\text { work }\end{array}$ & $\begin{array}{l}\text { Fine dust deposition on the cell has significant effect on power output. } \\
\text { Considered effects of due to air-borne dust concentration and } \\
\text { wind velocity. } \\
\text { Reported losses in solar intensity on cells, open-circuit voltage, } \\
\text { fill factor, short-circuit current and power as a function of } \\
\text { accumulation time. Power losses greater than } 95 \% \text {. }\end{array}$ & 11 \\
\hline India & $\begin{array}{l}\text { PV modules } \\
\text { (glass) }\end{array}$ & $\begin{array}{l}\text { Laboratory } \\
\text { work }\end{array}$ & $\begin{array}{l}\text { Loss of power due to accumulation of dust and increase in } \\
\text { temperature of the panel can be significant. }\end{array}$ & 95 \\
\hline
\end{tabular}


REVIEW ARTICLES

Table 2. (Contd)

\begin{tabular}{|c|c|c|c|c|}
\hline Location & $\begin{array}{l}\text { Type of } \\
\text { solar device }\end{array}$ & $\begin{array}{l}\text { Period } \\
\text { of study }\end{array}$ & Observations & Reference \\
\hline India & $\begin{array}{l}\text { PV modules } \\
\text { (glass) }\end{array}$ & 1 year & Reduction in current value due to dust is up to $30 \%$. & 96 \\
\hline Malaysia & PV modules & $\begin{array}{l}\text { Laboratory } \\
\text { experiment }\end{array}$ & $\begin{array}{l}18 \% \text { reduction in peak power when depositing dust on PV module. } \\
6 \% \text { power reduction difference between mud and talcum deposition. }\end{array}$ & 97 \\
\hline China & $\begin{array}{l}\text { PV modules } \\
\text { (glass) }\end{array}$ & & $\begin{array}{l}\text { Dust deposition layer } 0-22 \mathrm{~g} / \mathrm{cm}^{2} \text {; PV efficiency decreases by } 26 \% \\
\text { (linear relationship). No difference between cell types. }\end{array}$ & 98 \\
\hline Ghana & $\begin{array}{l}\text { PV system } \\
\text { (glass) }\end{array}$ & 4 years & $\begin{array}{l}\text { Effect of dust particles in the atmosphere generally lessens the solar } \\
\text { irradiance and vitality yield from the PV array. } \\
\text { Time of day data reported. } \\
\text { Cleaning by wiping of module surface. }\end{array}$ & 99 \\
\hline Nigeria & $\begin{array}{l}\text { Silicon solar } \\
\text { cells }\end{array}$ & 4 months & $\begin{array}{l}\text { Poor efficiency due to scattering of incoming radiation by } \\
\text { dust particles. }\end{array}$ & 100 \\
\hline Tokyo, Japan & $\begin{array}{l}\text { PV modules } \\
\text { (glass) }\end{array}$ & $\begin{array}{l}\text { Laboratory } \\
\text { experiment }\end{array}$ & $\begin{array}{l}\text { Varying the aspect ratio of PV cells used for PV modules results } \\
\text { in depletion in energy yield of } 80 \% \text { or less with } 3 \% \text { of spot } \\
\text { dirt on the module area. }\end{array}$ & 101 \\
\hline Spain & $\begin{array}{l}\text { PV modules } \\
\text { (glass) }\end{array}$ & 1 year & $\begin{array}{l}\text { During dry season, energy losses exceed } 20 \% \text { over a three-month period. } \\
\text { Annual average loss in PV output is } 4.4 \% \text { (with natural } \\
\text { cleaning by rainfall). } \\
\text { Proposed regular, periodic cleaning scheduled for modules. } \\
\text { A simple model has been provided stimulated with ray-tracing } \\
\text { methods to explain the behaviour of dust-induced loss in solar } \\
\text { PV modules. Both fixed and tracking systems of PV } \\
\text { panels have been considered. Time-of-day losses have been evaluated. }\end{array}$ & 102 \\
\hline Italy & $\begin{array}{l}\text { PV system } \\
(1 \mathrm{MW})\end{array}$ & & $\begin{array}{l}\text { Two 1-MW PV systems have been investigated. Soil type and } \\
\text { washing technique control the losses. There is } 6.9 \% \text { loss with } \\
\text { sandy soil and } 1.1 \% \text { with more compact soil. }\end{array}$ & 103 \\
\hline Libya & PV modules & $\begin{array}{l}\text { Outdoor } \\
\text { testing }\end{array}$ & $\begin{array}{l}\text { PV modules exposed for a period from February through May } \\
\text { in Sahara environment. Reported significant though } \\
\text { gradual reduction in power. } \\
\text { Weekly washing (water) kept power losses in the } 2-5 \% \text { range. }\end{array}$ & 104 \\
\hline
\end{tabular}

Table 3. Proposed cleaning techniques for different weather conditions

\begin{tabular}{|c|c|}
\hline Weather/area & Cleaning technique applied \\
\hline Desert & Vibrating the surface and aerodynamic streamlining ${ }^{40,104-107}$ \\
\hline Dry & Electrostatic biasing ${ }^{105}$, autonomous/robotic cleaning ${ }^{107,108}$, sprinkler ${ }^{105,109,110}$ \\
\hline Rainy, humid & Special techniques are not required, but can be combined with anti-reflective coating ${ }^{67,111,112}$. \\
\hline Cold, moist & Autonomous/robotic cleaning ${ }^{108}$, sprinkler $^{113}$ and anti-reflective coating ${ }^{67,111,112}$. \\
\hline Snow & Stowing/ inverting ${ }^{76,78}$, anti-reflective coating ${ }^{67,111}$ \\
\hline Hot, arid, sunny & Electrostatic biasing ${ }^{29,76,114}$, autonomous/robotic cleaning ${ }^{107}$, sprinkler. \\
\hline Cloudy, shaded & Autonomous/robotic cleaning ${ }^{107,108}$, sprinkler ${ }^{115}$, aerodynamic streamlining. \\
\hline
\end{tabular}

trapezoid-formed geared belt drives, providing the robot good flexibility in any desired direction. It can likewise be radio-controlled with a joystick for bigger applications.

Solar panel cleaning robot from $\mathrm{WashPanel}^{34}$ is completely autonomous, with double programmable operation through a rain sensor using water, whereas jets help in providing a steady and uniform cleaning. This framework is isolated, with conceivable supervision and administration from remote site and does not require any additional frame, support and added guides. It can be introduced on ground systems, buildings, peaked roof or shed roof. A text message sent from mobile phones, can permit command control from remote sites (Figure 5).

Heliostats Cleaning Team Oriented Robot (HECTOR) for heliostats can be used for SPV cleaning (Figure 6) ${ }^{35}$. 
It is a self-sufficient mobile SPV cleaning robot, which contains a cleaning solution tank. It is fused with sensors to work autonomously and navigates on its own over the SPV panel surface. Due to its autonomous nature, it does not require external power supply and has been made wireless and rechargeable. HECTOR is intended for night and day operations. Its execution is moderate and the weight of HECTOR is over the surface of panel. 'Solar

Table 4. Proposed cleaning techniques for different power generation capacities $^{107}$

\begin{tabular}{ll}
\hline Power generation & \multicolumn{1}{c}{ Cleaning technique proposed } \\
\hline Up to $1 \mathrm{~kW}$ & Human labour \\
$1-10 \mathrm{~kW}$ & Water sprinkler \\
$10-100 \mathrm{~kW}$ & Autonomous technique \\
More than $100 \mathrm{~kW}$ & Hybrid technique (coating + autonomous \\
& technique) \\
\hline
\end{tabular}

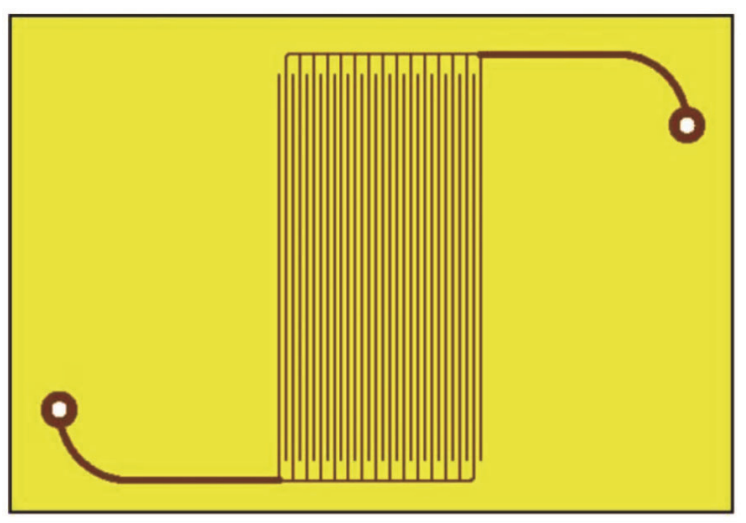

Figure 1. Single-phase electric curtain to create standing waves ${ }^{19}$.
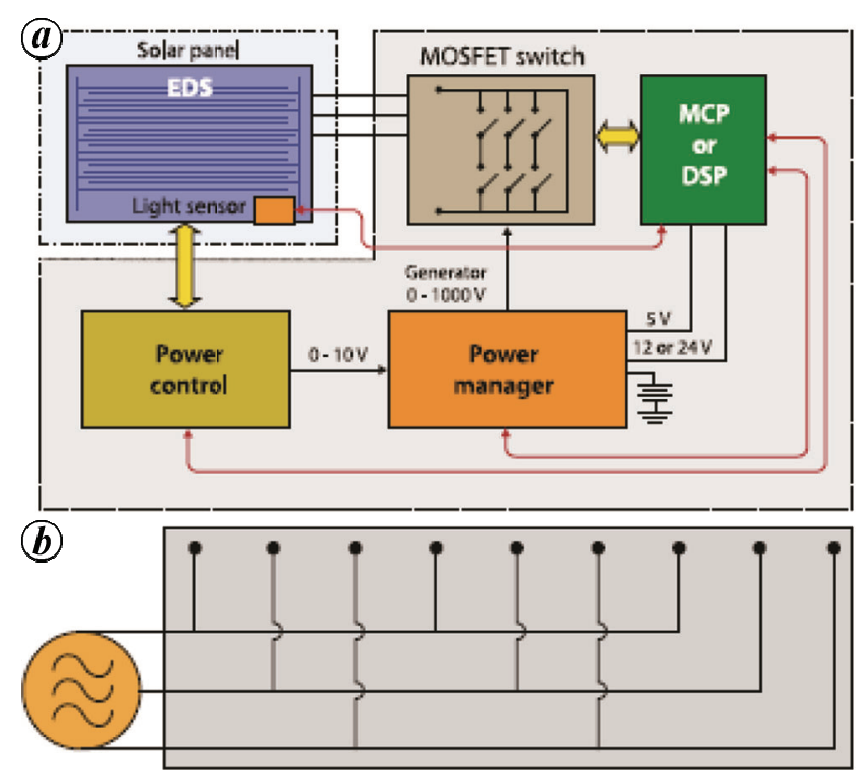

Figure 2. Electrodynamic screen with SPV array system: $\boldsymbol{a}$, Block diagram. $\boldsymbol{b}$, Three-phase electrode configuration ${ }^{28}$.

CURRENT SCIENCE, VOL. 115, NO. 6, 25 SEPTEMBER 2018 brush' is also a robotic cleaning system for SPV panels, which moves over the panels up to a slant of $35^{\circ}$ (Figure 7$)^{36}$. Solar brush is compact in size, wireless, and rechargeable with light weight $(2.5 \mathrm{~kg})$, which makes it apt for SPV cleaning; however, its performance rate is

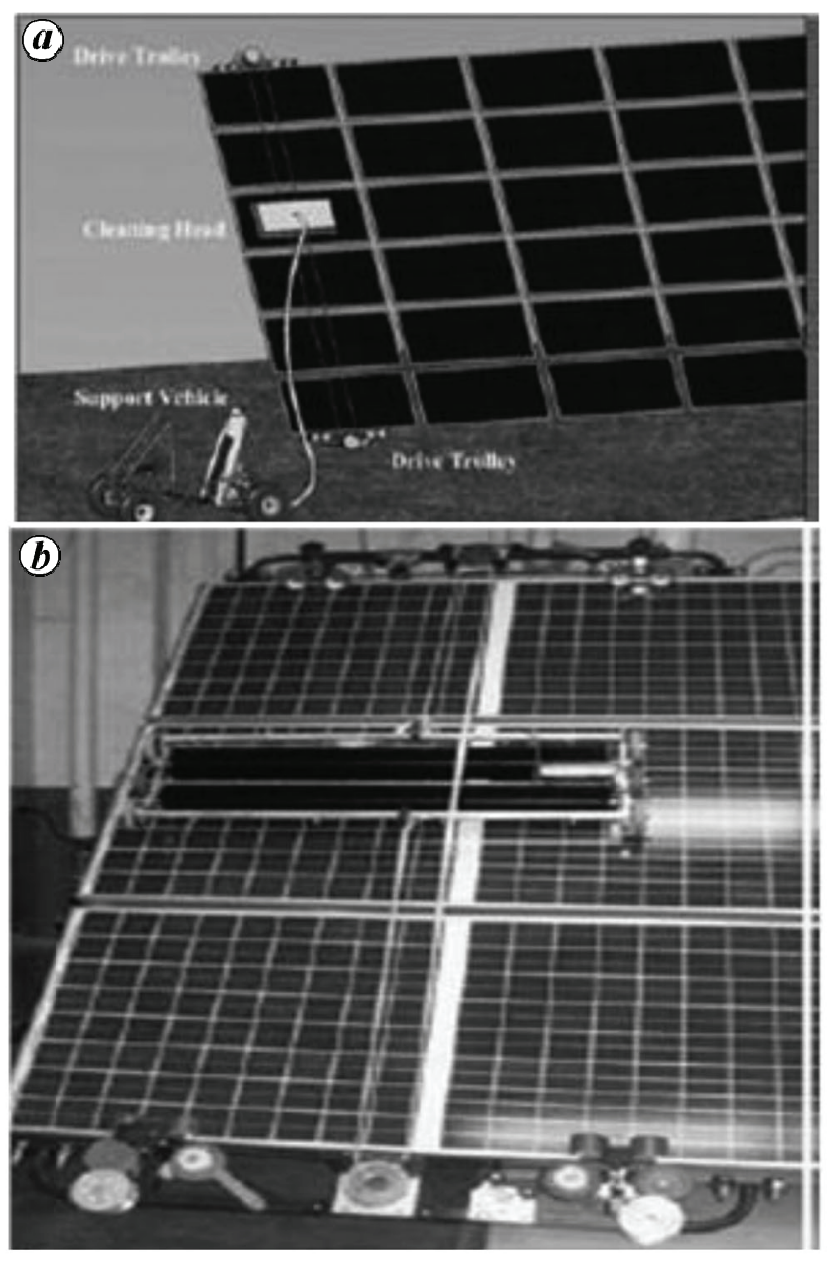

Figure 3. $\boldsymbol{a}$, Simulated operation of SPV $\operatorname{cleaner}^{31}$. $\boldsymbol{b}$, Cleaning of solar photovoltaic module using PV cleaner $^{31}$.

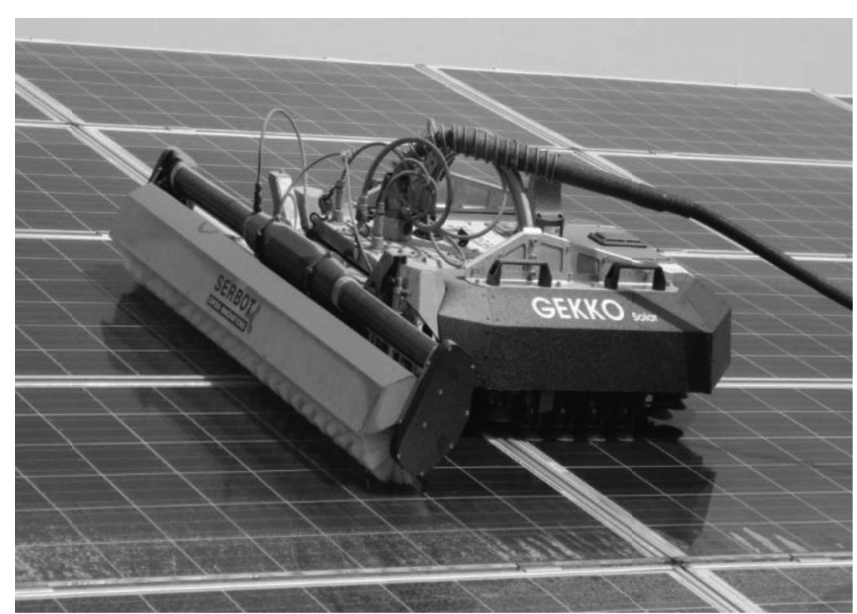

Figure 4. Gekko Solar for cleaning of SPV module ${ }^{32}$. 
very slow. 'GB1' from Greenbotics (now SunPower) is another robotic cleaning system for SPV panels (Figure $8)^{37}$. It involves rotating cleaning brushes normal to the axis of the panel and a wiper arrangement, useful for cleaning the panel as well as parallel cleaning of grimy

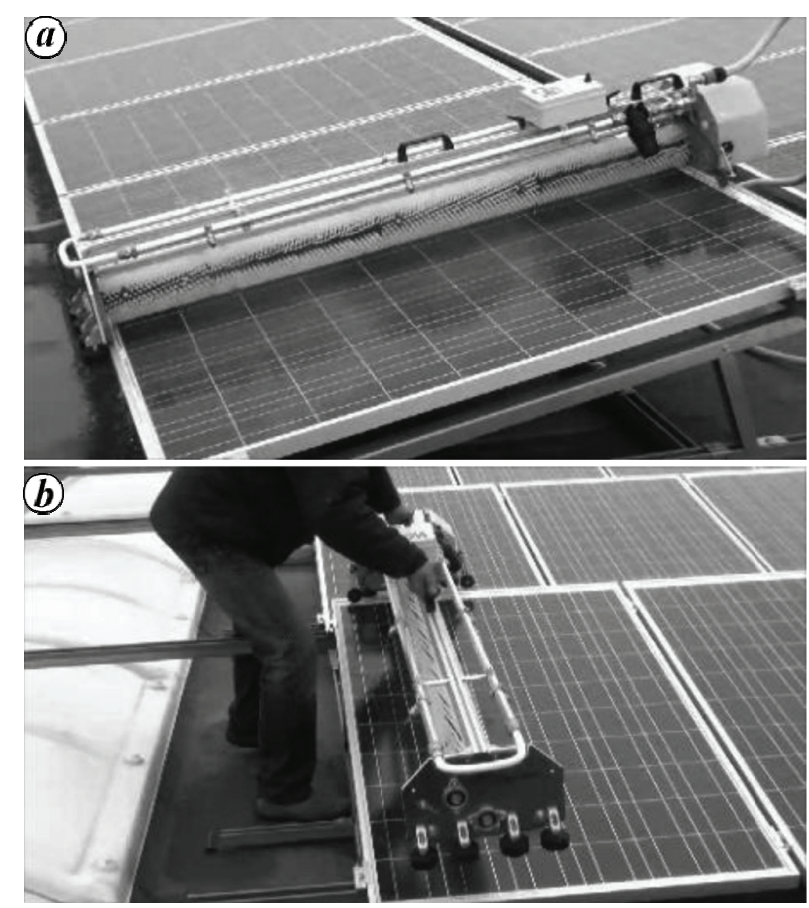

Figure 5. $\boldsymbol{a}$, WashPanel cleaning over $\mathrm{SPV}^{34}$. $\boldsymbol{b}$, Placement of wash panel over SPV module ${ }^{34}$.

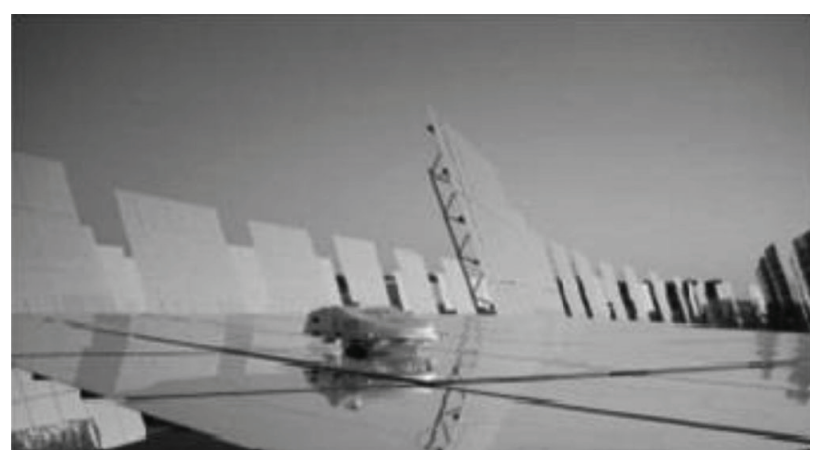

Figure 6. HECTOR robot cleaning SPV module ${ }^{35}$.

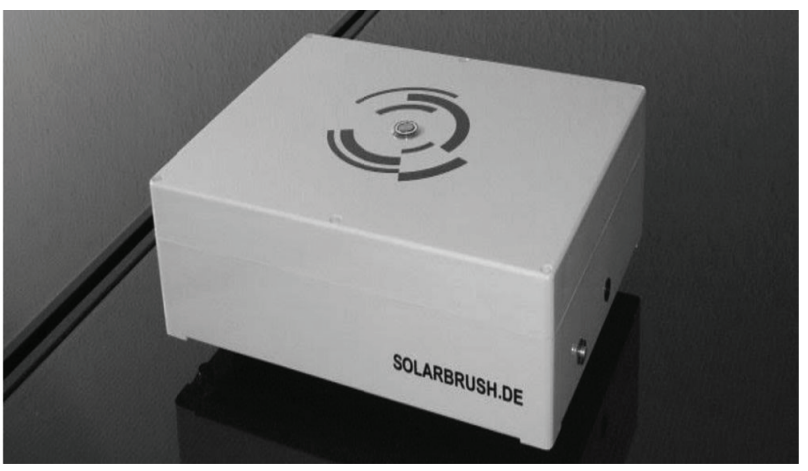

Figure 7. Solar brush cleaning SPV module ${ }^{36}$. water. It is therefore effective for all types of dust and bird droppings. Likewise, effective for single-axis tracking of SPV panels, GB1 moves at the edges of the frame of the panels (Figure 8). This is an added benefit as the direct weight of the set-up does not exceed that of the SPV panel.

Demo-based studies have been conducted, where PIC $^{38}$ microcontroller and PLC $^{39}$ were used for controlling the cleaning process (Figures 9 and 10). These set-ups use sensor data as input for navigation of cleaning head

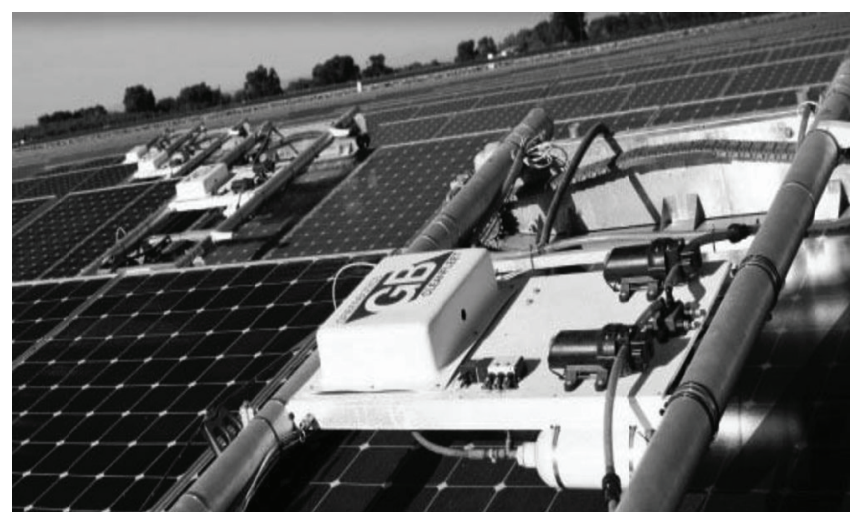

Figure 8. SPV cleaning robot from Greenbotics ${ }^{37}$.

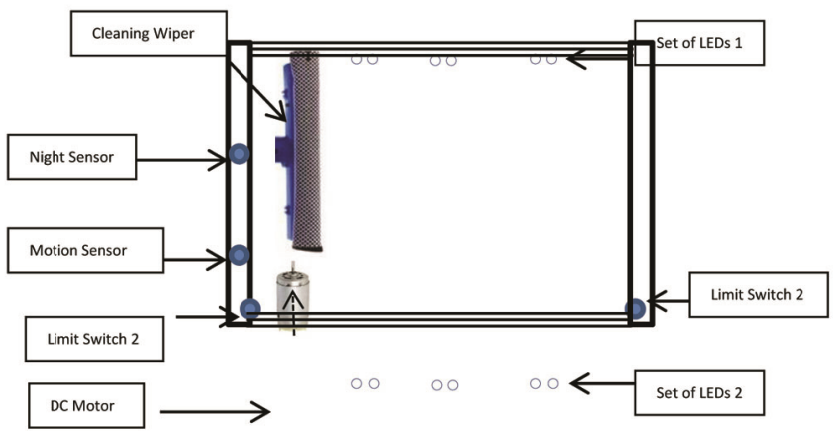

Figure 9. Mechanical design for cleaning SPV using PIC microcontroller ${ }^{38}$.

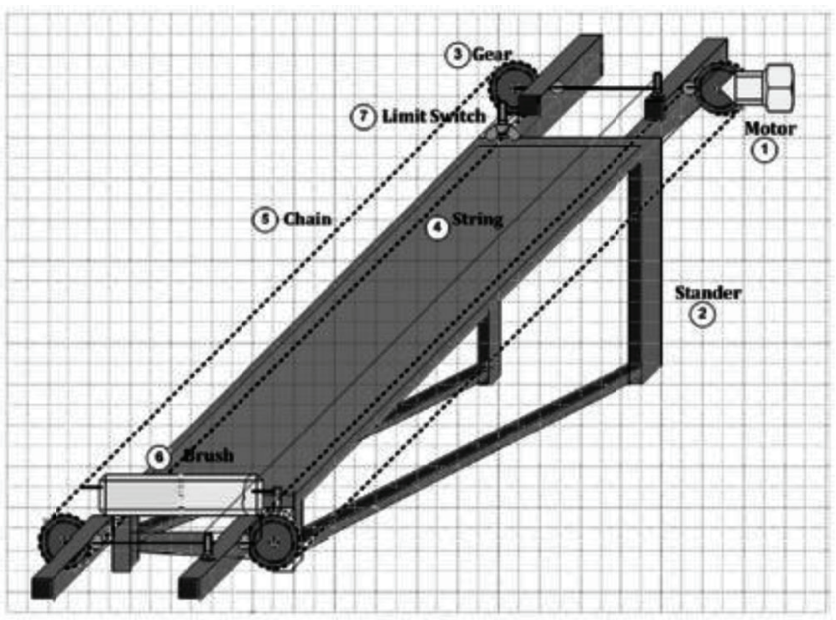

Figure 10. Mechanical design for cleaning SPV using PLC ${ }^{39}$.

CURRENT SCIENCE, VOL. 115, NO. 6, 25 SEPTEMBER 2018 
Table 5. Various types of cleaning systems ${ }^{107}$

\begin{tabular}{|c|c|c|}
\hline Cleaning system & Advantages & Challenges \\
\hline $\begin{array}{l}\text { Heliotex's 'automatic solar } \\
\text { panel cleaning system'116 }\end{array}$ & $\begin{array}{l}\text { Water spreads to every part of the SPV modules. } \\
\text { Aids in the cooling of SPV module, which } \\
\text { enhances the efficiency. }\end{array}$ & $\begin{array}{l}\text { Treated water required. } \\
\text { Filter has to be changed periodically. } \\
\text { Huge wastage of water. }\end{array}$ \\
\hline Gekko Solar ${ }^{32}$ & $\begin{array}{l}\text { Self-regulating and flexible, uninterrupted } \\
\text { cleaning process. }\end{array}$ & $\begin{array}{l}\text { Limitation of angle of tilt of SPV modules up to } 45^{\circ} \text {. } \\
\text { Added stresses on the surface due to gear, belt and } \\
\text { vacuum arrangement. }\end{array}$ \\
\hline Gekko Solar Farm ${ }^{117}$ & $\begin{array}{l}\text { Self-regulating and flexible, uninterrupted } \\
\text { cleaning process. }\end{array}$ & $\begin{array}{l}\text { Limitation of angle of tilt of SPV modules up to } 30^{\circ} \text {. } \\
\text { Complex gear, belt arrangement. }\end{array}$ \\
\hline Solar brush ${ }^{118}$ & $\begin{array}{l}\text { Automated robot } \\
\text { Works up to an angle of tilt of } 35^{\circ} \\
\text { It is rechargeable and wirelessly controlled. }\end{array}$ & $\begin{array}{l}\text { Heavy weight. } \\
\text { Initial investment cost is high. } \\
\text { Requires human intervention. } \\
\text { Very slow performance speed. }\end{array}$ \\
\hline $\begin{array}{l}\text { PIC microcontroller }{ }^{38} \text { and } \\
\text { PLC-based cleaning }\end{array}$ & $\begin{array}{l}\text { Self-regulating and flexible. Continuous } \\
\text { cleaning operations. }\end{array}$ & $\begin{array}{l}\text { Complex chain, sprocket-based structure. } \\
\text { Single SPV panel-based design. }\end{array}$ \\
\hline HECTOR $^{35}$ & $\begin{array}{l}\text { Compatible, integrated with all supplies. } \\
\text { Operational day and night. }\end{array}$ & $\begin{array}{l}\text { Slow performance. } \\
\text { Regular feeding needs to be done. }\end{array}$ \\
\hline Solar panel cleaning $\operatorname{robot}^{31}$ & Both washing and wiping processes are present. & $\begin{array}{l}\text { Chances of skid due to horizontal shifting of the robot over } \\
\text { the SPV module. } \\
\text { Causes stress on the surface of SPV module due to its own } \\
\text { weight. }\end{array}$ \\
\hline 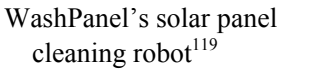 & Able to clean dust and bird droppings. & $\begin{array}{l}\text { Human intervention is required to start the operation and } \\
\text { while shifting from one row to another. }\end{array}$ \\
\hline $\begin{array}{l}\text { Sunpower-Greenbotic's } \\
\text { GB1 } 118 \text { (ref. 120) }\end{array}$ & Able to clean dust and bird droppings. & $\begin{array}{l}\text { Human intervention is required to start the operation } \\
\text { and while shifting from one row to another. }\end{array}$ \\
\hline
\end{tabular}

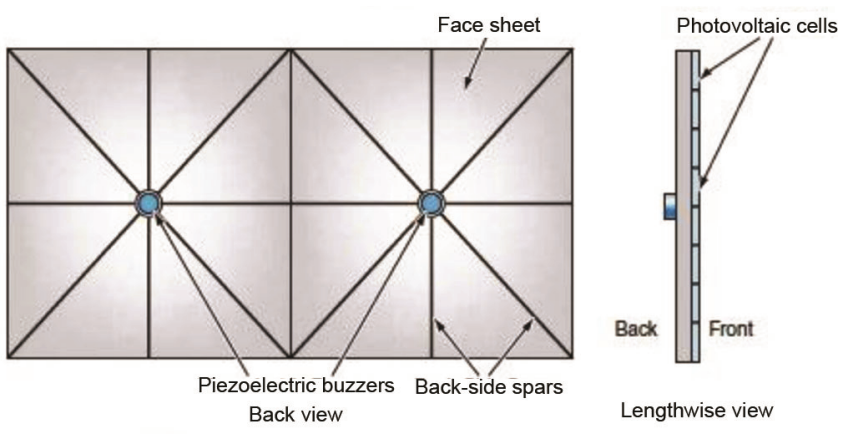

Figure 11. Placement of piezoelectric actuators at the back side of SPC panels (back view and lengthwise view) ${ }^{40}$.

over the SPV surface. The difference lies in the driving and controlling mechanism. While the PIC-based system uses direct motor coupling with the cleaning head for motion, PLC uses a chain belt-driven system. Table 5 provides a summary of the cleaning techniques.

\section{Surface vibrating}

Tilted SPV panels are vibrated to loosen the accumulated dust on the surface ${ }^{40}$. Piezoelectric actuators are used to create this vibration by placing the cross-sections of structural spars (say nodes), connected to the back of
SPV panels (Figure 11). Computational simulations by finite element method were used to optimize the exciting vibrations required for the SPV panel. Williams et al. ${ }^{41}$ found that excitations up to $5000 \mathrm{~Hz}$ gave best response for dust removal as the travelling waves of the dust get excited. Additionally, they remove dust and restore power by $95 \%$ of the power-generating capacity.

\section{Washing}

Washing of SPV panels is traditionally known for effective cleaning using centralized cleaning facilities. For optimizing the performance, it is better to clean the panels early in the morning and using pressure-induced demineralized water ${ }^{42,43}$. As the SPV surface is wet due to dew, it can be rinsed easily. Meanwhile, when SPV panel temperature becomes high (mid-noon), it requires more water and human effort to get the desired result.

The main prohibitive factors in this cleaning method are high volume of water consumption for each cleaning cycle, transportation of desalinized water to the solar plant and labour cost. However, using environmentfriendly chemical agents ${ }^{42,44}$ (passive surface treatments such as (super)hydrophobic, (super)hydrophilic and antisoiling coatings ${ }^{45-49}$, human effort and of water consumption could be reduced. 


\section{REVIEW ARTICLES}

Although availability of water is a major concern to implement this method at an industrial scale, washing solutions should possess the following attributes: non-toxic and biodegradable and easily mixable, handy and able to reduce surface tension.

\section{Automatic solar panel cleaning system}

Heliotex's automatic solar panel cleaning system automatically washes and rinses the SPV panels ${ }^{50}$. It attaches nozzles to SPV panels (Figure 12), along with a reservoir for concentrated cleanser. There is a silt channel containing water softner media. This system has an additional anti-siphon valve to prevent backwashing step, which comprises a controller for automatic wash and rinse cycles. The controller programming can be changed to suit seasonal needs. Such systems are beneficial for areas with limited manpower. Literature survey and laboratory tests show that high-pressure water sprays in the range $500-10,000$ psi can recover $95 \%$ of the original reflectance ${ }^{42,43,51}$.

\section{Prevention technique}

Prevention of dust deposition may help avoid the use of cleaning systems in SPV panels. This will help reduce the overall cost of energy production. The strategies to achieve this are discussed below.

\section{Surface modifications}

Figure 13 shows the various types of SPV panel materials. To minimize the shortcomings of each material, specific surface modifications have been applied. Surface recombination can significantly affect both the short-circuit current and open-circuit voltage, where high recombination rates at the top surface have a particularly harmful effect on short-circuit current. Since the charge generation depends on the light intensity which reaches near the junction and but the defects in the semiconductor mostly

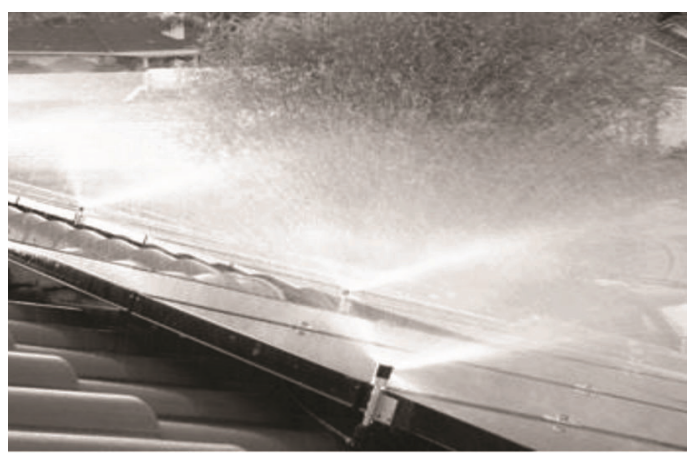

Figure 12. Heliotex's automatic solar panel cleaning system ${ }^{50}$. occurs at the surface which is a dominant recombination process and may affect SPV properties. Cutting down the high top-surface recombination is normally refined by reducing the amount of dangling silicon bonds at the top surface via passivation. Many electronics industries rely on the usage of thermally created silicon dioxide as well as silicon nitride layers to passivate the surface on account of low surrender states at the interface ${ }^{52}$. Since the passivating layer for silicon solar cells is normally an insulator, any region which has an ohmic metal contact cannot be passivated using silicon dioxide. Rather, under the top contacts the effect of surface recombination can be minimized by extending the doping, especially in situations where a high recombination surface is near the junction. The most reduced recombination option is to maximize doping. However, extreme doping can degrade the diffusion size. Subsequently, the effect on transporter accumulation becomes irrelevant. Presently, $\mathrm{TiO}_{2}$ nanotube layer based dye sensitized solar cells (DSSCs) are receiving more attention due to the favourable physical, optical and electrical properties of $\mathrm{TiO}_{2}$. Kang et al ${ }^{53}$ focused on developing $\mathrm{ZnO}$ coatings onto the $\mathrm{TiO}_{2}$ nanotube. They observed $\sim 20 \%$ improvement in efficiency after $\mathrm{ZnO}$ coating, which might be due to suppression of electron loss owing to straight electron flow and hindrance of charge recombination in the $\mathrm{TiO}_{2} /$ electrolyte. Mohamed et al. ${ }^{54}$ demonstrated the operational efficiency of an organic/ inorganic hybrid SPV cell through interface alteration with organic ligands. Jiang et $a l^{55}$ also reported the amalgamation and portrayal of $\mathrm{CdS}-$ thiophenol (CdS-PHSH) prepared by synthetic route.

This basic, low-cost technique transitions from using dangerous organometallic reagents to a new class of hybrid mixes of conjugated polymer (MEH-PPV)/CdSPHSH nanoparticles. Similar work was done by others to improve efficiency. Some researchers observed an efficiency of $0.6 \%$ with well-allied $\mathrm{CdS}$ nanorods/MEH-PPV SPV cells ${ }^{56}$. A higher efficiency of $1.17 \%$ has also been demonstrated using multi-armed CdS nanorods/MEHPPV SPV cells ${ }^{57,58}$. Shin et al. ${ }^{59}$ studied the impact of thermal annealing of CIGS films in air, sulphur, or selenium climates, and examined the impact of compositional and bond structure changes on the photovoltaic properties of CIGS SPV cells. They found that $\mathrm{Cu}$ movement in the CIGS film amid thermal strengthening assumed an essential part in enhancing cell structure and the arrangement deformities in CIGS bulk. Li et al. ${ }^{60}$ studied the surface alteration procedure to minimize surface recombination and manufacture productive, modern, dark silicon sunbased cells. In order to reduce surface reflectance, Agnanoparticles assisted etching was applied to form font surface nanostructures on silicon wafers. Over additional tetramethylammonium hydroxide (TMAH) treatment, the recombination at and close to the surface was stifled, which might be due to a lower surface dopant fixation after the surface change. The altered surface displayed 


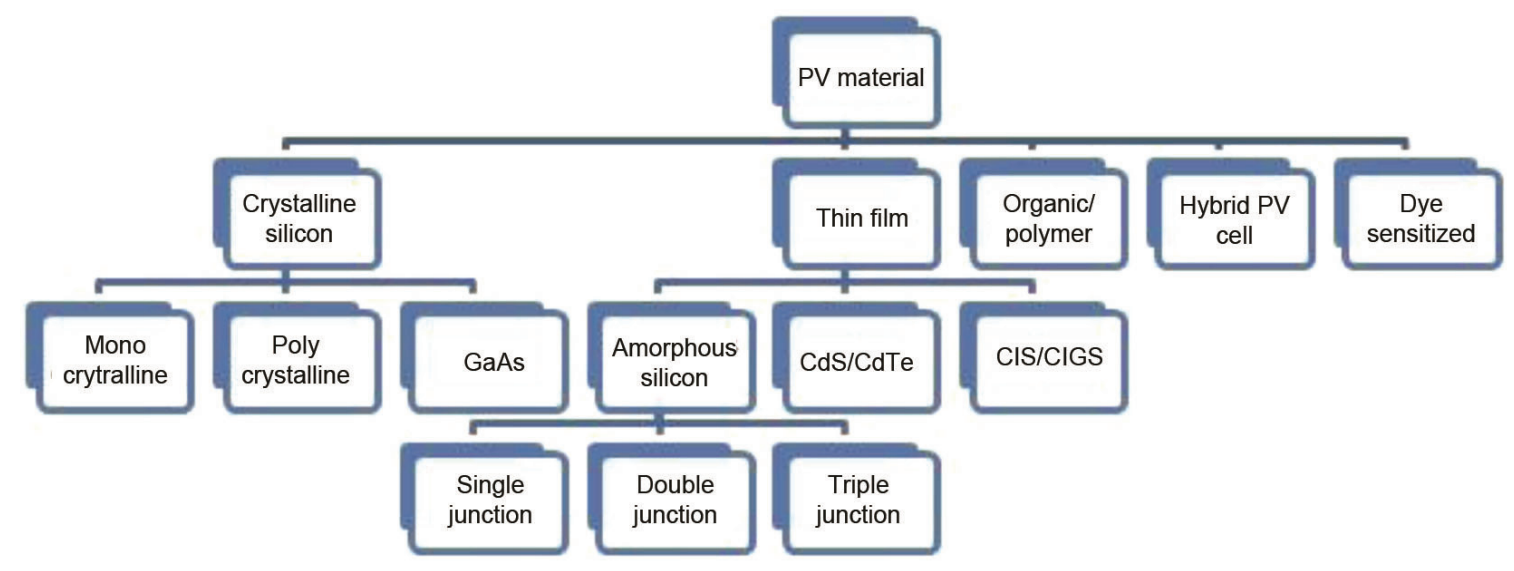

Figure 13. Different types of SPV materials.

low reflectivity in the range $350-1100 \mathrm{~nm}$ with an average conversion efficiency of $19.03 \%$, when TMAH treatment was performed for $30 \mathrm{sec}$. TNAH modified solar cells were $0.18 \%$ more efficient compared to black silicon solar cells without TMAH modification. Yang et $a l .{ }^{61}$ utilized 3-phosphonopropionic acid (3-PPA), butylphosphonic acid (BPA) and 3-aminopropylphosphonic acid (APPA) as self-amassed monolayers (SAMs) to alter the surface of $\mathrm{ZnO}$ nanorods. The results showed that SAMs not only passivated the surface deformities of $\mathrm{ZnO}$ nanorods, but also tuned their surface operation capacity to change the band arrangement of solar-powered cells. Specifically, the 3-PPA change shows the best passivation impact and makes the surface work function of $\mathrm{ZnO}$ decreases by $1.04 \mathrm{eV}$ to realize a better band alignment due to its electron-withdrawing tail group, which results in an enhancement in photovoltaic conversion efficiency of solar cells. Tang et al. ${ }^{62}$ have critically studied the upgradation proficiency of $\mathrm{ZnO}$-nanorods-based natural/ inorganic SPV cells with turn covered P3HT: PCBM mix as dynamic layer. The performance of the fabricated device was enhanced by surface adjustment of $\mathrm{ZnO}$ with poly[(4,4'-bis(2-ethylhexyl)dithieno[3,2-b:2',3'-d] silole)2,6-diyl-alt-(2,1,3-benzothiadiazole)-4,7-diyl] (PSBTBT) ${ }^{63}$. Optimized device of ITO/ZnO nanorod/P3HT: PCBM/Ag device with PSBTBT surface adjustment and air introduction helped achieve an effectiveness of $2.02 \%$ with a short circuit current density including open-circuit voltage and fill component of $13.23 \mathrm{~mA} / \mathrm{cm}^{2}, 0.547 \mathrm{~V}$ and $28 \%$, individually, under AM 1.5 illumination of $100 \mathrm{~mW} / \mathrm{m}^{2}$. Compared to unmodified cells, a seven-fold increment in the productivity of the PSBTBT surface altered ITO/ZnO nanorods/P3HT : PCBM/Ag device was observed. Xiang et al. ${ }^{64}$ altered nanoporous $\mathrm{TiO}_{2}$ films with $\mathrm{ZrCl}_{4} / \mathrm{TiCl}_{4}$ blended arrangements, where a changed layer involving $\mathrm{ZrO}_{2}$ and $\mathrm{TiO}_{2}$ was framed onto the surface of $\mathrm{TiO}_{2}$ photo-electrodes. They also observed an increment in conversion efficiency by $18.67 \%$ (from $6.21 \%$ to $7.37 \%$ ), when $\mathrm{TiO}_{2}$ films were modified with a mixed solution of $0.05 \mathrm{~mol} \mathrm{l}^{-1} \mathrm{ZrCl}_{4}$ and $0.04 \mathrm{~mol} \mathrm{l}^{-1}$ $\mathrm{TiCl}_{4}$.

\section{Surface coatings}

Surface coatings deal with the glass covering surface of SPV panels and help prevent dust from sticking to the surface. There are several types of surface and helpful coatings available for the panels depending upon the major vulnerability of dust attack and type ${ }^{65}$ : (i) hydrophobic type, which has less affinity towards ionic species $^{66,67}$, (ii) low surface energy type, which lowers the surface chemical reaction; (iii) chemical type, which reacts with sticky dusts and (iv) oil coatings.

Hydrophobic coatings cause high contact angle between SPV surface and water droplets, making the droplets roll freely over the SPV surface, thus removing the dust. Chemical replacement of group I ion with groups II or III creates water-resistant solution or hydrophilic nature. Hydrophilic solutions are designed to resist dust accumulation and sheeting of water enables an effective cleaning of SPV surface (Figure 14). Various types of coating mixtures are now being explored. However, these are commercially unsuccessful as prolonged exposure to UV radiation causes permanent damage to the coatings ${ }^{68}$, affecting the durability as wind and sand can cause erosion.

Oil coatings like natural oil (sunflower) and mineral oil (vacuum pump oil), engine oil and brake oil are used to coat ( $>1 \mathrm{~mm}$ thick) the exposed surface of SPV panels. In fact, mineral oil coating shows $24 \%$ more transmissivity compared to normal glass ${ }^{69}$. Hence the same can be applied over SPV glass mounting with anti-reflection coatings $^{70}$.

Tuff $\mathrm{Fab}^{71}$ is a coating solution which is easy to apply, making the glass surface non-sticky and effortless to clean. Tuff Fab does not require harsh chemicals and scrubbing to clean the SPV panels. Using this approach, clean water or mellow cleanser and an wipe with a soft 


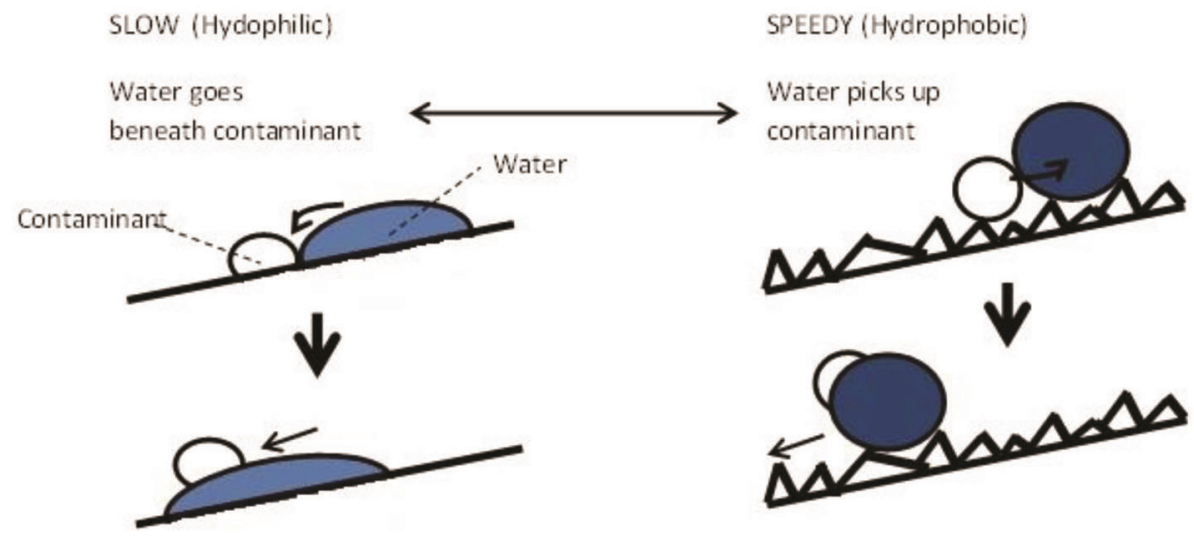

Figure 14. Hydrophilic and hydrophobic surface cleaning processes.

Table 6. Various types of industrial coating systems

\begin{tabular}{lll}
\hline Coating system & \multicolumn{1}{c}{ Advantages } & \multicolumn{1}{c}{ Shortcomings } \\
\hline Tuff Fab's Nano Clear ${ }^{71}$ & Long-lasting & Cleaning is required, but with less effort. \\
Asahi Kasei Corporation's SPV coating & High transmittance capability & Cleaning is required, but with less effort. \\
\hline
\end{tabular}

towel will clean the SPV panels. Researchers ${ }^{72,73}$ have implemented many other products similar to Tuff Fab (Table 6).

\section{Aerodynamic streamlining}

This uses air flow (preferable forced air) for removing dust from the SPV surface. In this method, special type of turbidity spoiler is positioned along SPV panels to create turbulent-flow due to an aerodynamic arrangement. This provides rotational and translational motion to impart scrubbing action to the gas flow, which can sweep off dust from the surface ${ }^{74-77}$. Key parameters like velocity, duration, angle of incidence and type of gas play a vital role in forced air cleaning.

\section{Stowing/inverting of $S P V$}

During night and dusty storm condition, tracking-enabled SPV panels can be inverted or stowed to prevent major dust accumulation ${ }^{76}$. Roth and Pettit $^{78}$ have shown that panel orientation at $180^{\circ}$ (inverted) and $90^{\circ}$ can reduce soiling.

\section{Conclusion and future perspective}

Cleaning and prevention are two main options to counter the deposition problem in SPV panels. Cleaning can be achieved by various manual processes, but they seem to be energy-intensive and time-consuming efforts. Automatic robotic system has been successfully employed, but the additional maintenance and energy consumption always remain a point of debate for commercial applications. In terms of prevention, coating seems to be a good approach, as it is effective in protecting the surface from harmful deposition. However, transparency of coating material is always a challenge for this approach. Additionally, impact of environment on the stability of coating is area of concern. Also, limited research on measurement and quantification of SPV coating limits the development of a successful system with long-term applications. Furthermore, coating-based research is currently at an experimental level and more studies are required for its effective commercialization. This is a challenging task and demands more precise structural engineering. Undoubtedly, there is need for a new, self-healing coating material with high flexibility, transparency for construction of stable and flexible SPV devices. The coating should also be impervious to oxygen and moisture. Dust deposition on SPV panels limits their efficiency and remains a challenging parameter to improve the performance of the overall system. In general, it may be concluded that dust will be a continuous challenge for SPV panels, particularly in desert areas. Lack of natural cleaning like rainfall and shortage of water resources increase the severity of the problem. Additionally, dew/moisture leads to cementation of dust. Stowing, inverting and vibration techniques could be considered as simple and robust approaches to prevent the build-up of dust. Adequately transparent, durable coating will be required for effective performance, preservation and enhancement of SPV panels. Sensors to detect the critical point for cleaning of surfaces are also required so that simultaneously hot point, partial shading, etc. can also be solved. Depending 
on the environmental and geographical requirements as well as solar plant capacity, hybrid (mixed) techniques are recommended.

1. Jacobson, M. Z. and Delucchi, M. A., Providing all global energy with wind, water, and solar power, Part I: technologies, energy resources, quantities and areas of infrastructure, and materials. Energ. Policy, 2011, 39(3), 1154-1169.

2. Good, C., Environmental impact assessments of hybrid photovoltaic-thermal (PV/T) systems - a review. Renew. Sust. Energ. Rev., 2016, 55, 234-239.

3. Akbarzadeh, A. and Wadowski, T., Heat pipe-based cooling systems for photovoltaic cells under concentrated solar radiation. Appl. Therm. Eng., 1996, 16(1), 81-88.

4. Moharram, K. A., Abd-Elhady, M. S., Kandil, H. A. and El-Sherif, H., Enhancing the performance of photovoltaic panels by water cooling. Ain Shams Eng. J., 2013, 4(4):869-877.

5. Moharram, K. A., Abd-Elhady, M. S., Kandil, H. A. and El-Sherif, H., Influence of cleaning using water and surfactants on the performance of photovoltaic panels. Energ. Convers. Manage., 2013, 68, 266-272.

6. Sera, D. and Baghzouz, Y. (eds), On the impact of partial shading on PV output power. In WSEAS/IASME International Conference on Renewable Energy Sources (RES'08), Corfu, Greece, 2008 .

7. Nahar, N. and Gupta, J. P., Effect of dust on transmittance of glazing materials for solar collectors under arid zone conditions of India. Sol. Wind Technol., 1990, 7(2), 237-243.

8. Kaldellis, J. and Kapsali, M., Simulating the dust effect on the energy performance of photovoltaic generators based on experimental measurements. Energy, 2011, 36(8), 5154-5161.

9. Mani, M. and Pillai, R., Impact of dust on solar photovoltaic (PV) performance: research status, challenges and recommendations. Renew. Sustain. Energ. Rev., 2010, 14(9), 3124-3131.

10. Hottel, H. and Woertz, B., Performance of flat-plate solar-heat collectors. Trans ASME, 1942, 64

11. Goossens, D. and Van Kerschaever, E., Aeolian dust deposition on photovoltaic solar cells: the effects of wind velocity and airborne dust concentration on cell performance. Sol. Energy, 1999, 66(4), 277-289.

12. Rolland, J., Astier, S. and Protin, L., Static device for improving a high voltage photovoltaic generator working under dusty conditions. Sol. Cells, 1990, 28(4), 277-286.

13. Sims, R. et al. (eds), Development of a transparent self-cleaning dust shield for solar panels. In Proceedings ESA-IEEE Joint Meeting on Electrostatics, University of Arkansas, Little Rock, Arkansas, 2003.

14. Levinson, R., Berdahl, P., Berhe, A. A. and Akbari, H., Effects of soiling and cleaning on the reflectance and solar heat gain of a light-colored roofing membrane. Atmos. Environ., 2005, 39(40), 7807-7824

15. Liu, G. and Marshall, J., Particle transport by standing waves on an electric curtain. J. Electrostat., 2010, 68(4), 289-298.

16. Liu, G. and Marshall, J., Effect of particle adhesion and interactions on motion by traveling waves on an electric curtain. $J$. Electrostat., 2010, 68(2), 179-189.

17. Sharma, R., Wyatt, C. A., Zhang, J., Calle, C. I., Mardesich, N and Mazumder, M. K., Experimental evaluation and analysis of electrodynamic screen as dust mitigation technology for future Mars missions. IEEE Trans. Indus. Appl., 2009, 45(2), 591-596.

18. Calle, C., Buhler, C., McFall, J. and Snyder, S., Particle removal by electrostatic and dielectrophoretic forces for dust control during lunar exploration missions. J. Electrostat., 2009, 67(2), 89-92.

19. Atten, P., Pang, H. L. and Reboud, J.-L., Study of dust removal by standing-wave electric curtain for application to solar cells on mars. Industry applications. IEEE Trans., 2009, 45(1), 75-86.

20. Qian, D., Marshall, J. and Frolik, J., Control analysis for solar panel dust mitigation using an electric curtain. Renew. Energ., 2012, 41, 134-144.

21. Calle, C. et al. (eds), Dust particle removal by electrostatic and dielectrophoretic forces with applications to NASA exploration missions. In Proceedings of ESA Annual Meeting on Electrostatics, Minneapolis, MN, 2008.

22. Sayyah, A., Crowell, D. R., Raychowdhury, A., Horenstein, M. N. and Mazumder, M. K., An experimental study on the characterization of electric charge in electrostatic dust removal. J. Electrostat., 2017, 87, 173-179.

23. Masuda, S. and Matsumoto, Y. (eds), Contact-type electric curtain for electrodynamical control of charged dust particles. In Proceedings of the 2nd International Conference on Static Electricity, 1973.

24. Masuda, S., Fujibayashi, K., Ishida, K. and Inaba, H., Confinement and transportation of charged aerosol clouds via electric curtain. Electr. Eng. Jpn., 1972, 92(1), 43-52.

25. Pohl, H. A. and Pohl, H., Dielectrophoresis: The Behavior of Neutral Matter in Nonuniform Electric Fields, Cambridge University Press, Cambridge, UK, 1978.

26. Jones, T., Electromechanics of Particles, Cambridge University Press, Cambridge, UK, 1995.

27. Mazumder, M. K., Sims, R. A. and Wilson, J. D., Transparent self-cleaning dust shield. Google Patents, 2005.

28. Bock, J. P. et al. (eds), An efficient power management approach for self-cleaning solar panels with integrated electrodynamic screens. Proc ESA Annual Meeting on Electrostatics, Minneapolis, MN, 2008.

29. Biryukov, S. et al. (eds), A new method of dust removal for PV-panels by means of electric fields. In 25th European Photovoltaic Solar Energy Conference and Exhibition / 5th World Conference on Photovoltaic Energy Conversion, Valencia, Spain, 2010 .

30. Clark, P. et al. (eds) SPARCLE: electrostatic tool for lunar dust control. In AIP Conference Proceedings, Huntsville (Alabama), 2009.

31. Anderson, M. et al., Robotic device for cleaning photovoltaic panel arrays, 2009; https://www.worldscientific.com/doi/abs/ $10.1142 / 97898142912790047$

32. www.serbot.ch/images/documents/TD GEKKO\%20Solar En 2013 06_06.pdf

33. http://serbot.ch/images/documents/Serbot $\% 20$ Success $\% 20$ Story Belectric En 2012 12.pdf

34. http://www.washpanel.com/en/documenti.php

35. http://www.sener.es/revista-sener/en/n44/up-to-date new markets. html

36. http://www.solarbrush.de/about

37. www.greenbotics.com/news.html

38. Al-Qubaisi, E. et al. (eds), EPECS'09 International Conference on Microcontroller based dust cleaning system for a standalone photovoltaic system. In Electric Power and Energy Conversion Systems, University of Arkansas, Little Rock, Arkansas, 2009.

39. Al-Dhaheri, S. et al. (eds), Automated design for boosting photovoltaic (PV) performance offshore. In Proceedings of Electric Power and Energy Conversion Systems Transmission and Distribution Conference and Exposition, New Orleans, USA, 2010.

40. Dawson, S., Mardesich, N., Spence, B. and White, S., Solar array panels with dust-removal capability. NASA Tech. Briefs, 2004, 20.

41. Williams, R. B., Tanimoto, R., Simonyan, A. and Fuerstenau, S. (eds). Vibration characterization of self-cleaning solar panels with piezoceramic actuation. 48th AIAA/ASME/ASCE/AHS/ ASC Structures. In Structural Dynamics, and Materials Conference, 2007. 
42. Morris, V. L., Cleaning agents and techniques for concentrating solar collectors. Sol. Energ. Mater., 1980, 3(1), 35-55.

43. Hoffman, A. and Maag, C. R., Photovoltaic module soiling studies, May 1978-October 1980; https://www.sciencedirect.com/ science/article/pii/0165163380900489

44. Sheratte, M., Cleaning agents and techniques for concentrating solar collectors: McDonnell Douglas Astronautics Co, West, Huntington Beach, CA, USA, 1980.

45. Cuddihy, E. F., Surface soiling: theoretical mechanisms and evaluation of low soiling coatings. Williamsburg, VA, USA, 1983, pp. 379-96.

46. Sueto, T., Ota, Y. and Nishioka, K., Suppression of dust adhesion on a concentrator photovoltaic module using an anti-soiling photocatalytic coating. Sol. Energ., 2013, 97, 414-417.

47. Midtdal, K. and Jelle, B. P., Self-cleaning glazing products: a state-of-the-art review and future research pathways. Sol. Energ. Mater. Sol. Cells, 2013, 109, 126-141.

48. Hirohata, T., Ota, Y. and Nishioka, K. (eds), Effect of anti-soiling coating on performance of Fresnel lens for concentrator photovoltaic module. Appl. Mech. Mater., 2013, 372, 575-578.

49. John, J. J. et al. (eds), Novel PV module cleaning system using ambient moisture and self-cleaning coating. In Photovoltaic Specialists Conference (PVSC), 39th IEEE, 2013.

50. http://www.solarpanelcleaningsystems.com/solar-panel-cleaningservices.php

51. Muller, J., Study of chemicals for solar mirror cleaning: final report. Number $78622335 \mathrm{H}$ McDonnell Douglas Astronautics Company, USA, 1979.

52. Eades, W. D. and Swanson, R. M., Calculation of surface generation and recombination velocities at the $\mathrm{Si}-\mathrm{SiO}_{2}$ interface. J. Appl. Phys., 1985, 58(11), 4267-476.

53. Kang, S. H., Kim, J.-Y., Kim, Y., Kim, H. S. and Sung, Y.-E., Surface modification of stretched $\mathrm{TiO}_{2}$ nanotubes for solid-state dye-sensitized solar cells. J. Phys. Chem. C, 2007, 111(26), 9614-9623.

54. Mohamed, N. B. H., et al., Role of surface modification of CdS nanoparticles on the performance of hybrid photovoltaic devices based on $p$-phenylenevinylene derivate. Physica E, 2015, 69, $145-152$.

55. Jiang, X. et al., Effects of molecular interface modification in $\mathrm{CdS} /$ polymer hybrid bulk heterojunction solar cells. Sol. Energ. Mater. Solar Cells, 2010, 94(12), 2223-2229.

56. Kang, Y. and Kim, D., Well-aligned CdS nanorod/conjugated polymer solar cells. Sol. Energ. Mater. Sol. Cells, 2006, 90(2), 166-174.

57. Wang, L., Liu, Y., Jiang, X., Qin, D. and Cao, Y., Enhancement of photovoltaic characteristics using a suitable solvent in hybrid polymer/multiarmed CdS nanorods solar cells. J. Phys. Chem. C, 2007, 111(26), 9538-9542.

58. Chen, F. et al., Large-scale fabrication of CdS nanorod arrays on transparent conductive substrates from aqueous solutions. Sol. Energ., 2011, 85(9), 2122-2129.

59. Shin, Y. M., Lee, C. S., Shin, D. H., Kwon, H. S., Park, B. G. and Ahn, B. T., Surface modification of CIGS film by annealing and its effect on the band structure and photovoltaic properties of CIGS solar cells. Curr. Appl. Phys., 2015, 15(1), 18-24.

60. Li, P. et al., Highly efficient industrial large-area black silicon solar cells achieved by surface nanostructured modification. Appl. Surf. Sci., 2015, 357(Part B), 1830-1835.

61. Yang, L. et al., Effects of interface modification with selfassembled monolayers on the photovoltaic performance of CdS quantum dots sensitized solar cells. Electrochim. Acta, 2015, 164, 38-47.

62. Tang, S., Tang, N., Meng, X., Huang, S. and Hao, Y., Enhanced power efficiency of $\mathrm{ZnO}$ based organic/inorganic solar cells by surface modification. Phys. E, 2016, 83, 398-404.
63. Lv, H., Zhao, X., Xu, W., Li, H., Chen, J. and Yang, X., Improving performance of polymer solar cells based on PSBTBT/ PC71BM via controlled solvent vapor annealing. Organ. Electron., 2013, 14(7), 1874-1881.

64. Xiang, Y., Yu, J., Zhang, T., Wen, Q., Zhuang, J. and Guo, J., Improved performance of nanoporous $\mathrm{TiO}_{2}$ film in dye-sensitized solar cells via $\mathrm{ZrCl}_{4}$ and $\mathrm{TiCl}_{4}$ surface co-modifications. Mater. Sci. Semicond. Process., 2016, 49, 48-53.

65. Cuddihy, E. F., Theoretical considerations of soil retention. Sol. Energ. Mater., 1980, 3(1), 21-33.

66. Nishioka, K. et al. (eds), Anti-soiling layer coarted on PMMA Fresnel lens for concentrator photovoltaic modules. In 37th IEEE Photovoltaic Specialists Conference (PVSC), 2011.

67. Miller, D. C. and Kurtz, S. R., Durability of Fresnel lenses: a review specific to the concentrating photovoltaic application. Sol. Energ. Mater. Sol. Cells, 2011, 95(8), 2037-2068.

68. Niu, J. J., Wang, J. N. and Xu, Q. F., Synthesis of superhydrophobic silicon oxide nanowires surface on silicon wafer. J. Nanosci. Nanotechnol., 2009, 9(3), 1819-1824.

69. Abd-Elhady, M., Fouad, M. and Khalil, T., Improving the efficiency of photovoltaic (PV) panels by oil coating. Energ. Convers. Manage., 2016, 115, 1-7.

70. http://www.dsm.com/corporate/markets-products/markets/energy/ anti-reflective-coating.html

71. http://www.tufffab.com/nano-clear.html

72. Watanabe, K. et al. (eds), Self-assembled $\mathrm{SiO}_{2}$ particle coating on 2 layer anti-reflection films for efficiency enhancement of GaAs PV cells. In 35th IEEE Photovoltaic Specialists Conference (PVSC), 2010.

73. Ji, L. and Varadan, V. V., Fishnet metastructure for efficiency enhancement of a thin film solar cell. J. Appl. Phys., 2011, 110(4), 043114.

74. Slocum, A. H., Figueredo, S. and Kazem, B. I., Vortex-induced cleaning of solar panel surfaces. Google Patents, 2013.

75. Kok, J. F., Parteli, E. J., Michaels, T. I. and Karam, D .B., The physics of wind-blown sand and dust. Rep. Prog. Phys., 2012, 75(10), 106901.

76. Sarver, T., Al-Qaraghuli, A. and Kazmerski, L. L., A comprehensive review of the impact of dust on the use of solar energy: history, investigations, results, literature, and mitigation approaches. Renew. Sust. Energ. Rev., 2013, 22, 698733.

77. Kimura, R., Effect of the strong wind and land cover in dust source regions on the Asian dust event over Japan from 2000 to 2011. SOLA, 2012, 8(0), 77-80.

78. Roth, E. P. and Pettit, R. B., The effect of soiling on solar mirrors and techniques used to maintain high reflectivity. Solar Mater. Sci., 1980, 1, 199-227.

79. Dietz, A. G., Diathermanous materials and properties of surfaces. Space Heating Solar Energy, 1963.

80. Anagnostou, E. and Forestieri, A. (eds), Endurance testing of first generation/Block I/commercial solar cell modules. In 13th Photovoltaic Specialists Conference, 1978.

81. Kimber. A. et al. (eds), The effect of soiling on large gridconnected photovoltaic systems in California and the southwest region of the United States. In Photovoltaic Energy Conserved, Conference Record of the 2006 IEEE 4th World Conference, 2006.

82. Murphy, E. B. and Forman, S. E. (eds), Measuring dirt on photovoltaic modules. In The Enigma of the Eighties: Environment, Economics, Energy. Proceedings of the Twenty-fourth National Symposium and Exhibition, San Francisco, Calif, 8-10 May 1979 Book 1 (A79-43228 18-23) Azusa, Calif, Society for the Advancement of Material and Process Engineering, 1979, pp. 717-727; Research sponsored by the US Department of Energy, 1979. 
83. Forman, S. (ed.) Photovoltaic module performance and degradation at various MIT/LL test sites. Sun II, 1979.

84. Ryan, C., Vignola, F. and McDaniels, D., Solar cell arrays: degradation due to dirt. Proc Am. Sect. Int. Sol. Energ. Soc., 1989, pp. 234-237.

85. Sayigh, A. (ed.), Effect of dust on flat plate collectors. In Sun: Mankind's Future Source of Energy, Proceedings of the International Solar Energy Society Congress, Elsevier, 1978.

86. El-Shobokshy, M., Mujahid, A. and Zakzouk, A., Effects of dust on the performance of concentrator photovoltaic cells. IEEE Proc. I, Solid-State Electron Dev., 1985, 132(1), 5-8.

87. Zakzouk, A. and Electrochem, M., On the dust-equivalent series resistance of a photovoltaic concentrator. IEEE Proc. I, SolidState Electron Dev., 1984, 131(1), 17-20.

88. Al-Hasan, A. Y. and Ghoneim, A. A., A new correlation between photovoltaic panel's efficiency and amount of sand dust accumulated on their surface. Int. J. Sust. Energ.,. 2005, 24(4), 187-197.

89. Nimmo, B. and Said, S. A. (eds), Effects of dust on the performance of thermal and photovoltaic flat plate collectors in Saudi Arabia-Preliminary results. Altern. Energ. Sources II, 1981, 1.

90. Alamoud, A., Performance evaluation of various photovoltaic modules in hot and arid environment. Proc. Int. Energ. Conver., 1993.

91. Said, S., Effects of dust accumulation on performances of thermal and photovoltaic flat-plate collectors. Appl. Energ., 1990, 37(1), 73-84.

92. Wakim, F., Introduction of PV power generation to Kuwait. Kuwait Institute for Scientific Researchers, Kuwait City, 1981.

93. Ibrahim, A., Effect of shadow and dust on the performance of silicon solar cell. J. Basic Appl. Sci. Res., 2011, 1(3), 222-230.

94. Elminir, H. K., Ghitas, A. E., Hamid, R., El-Hussainy, F., Beheary, M. and Abdel-Moneim, K. M., Effect of dust on the transparent cover of solar collectors. Energ. Convers. Manage, 2006, 47(18), 3192-3203.

95. Kattakayam, T. A., Khan, S. and Srinivasan, K., Diurnal and environmental characterization of solar photovoltaic panels using a PC-AT add on plug in card. Solar Energ. Mater. Solar Cells, 1996, 44(1), 25-36.

96. Pande, P. (ed.), Effect of dust on the performance of PV panels. In 6th International Photovoltaic Science and Engineering Conference, New Delhi, 1992.

97. Sulaiman, S. A., Hussain, H. H., Leh, N. S. H. N. and Razali, M. S., Effects of dust on the performance of PV panels. World Acad. Sci., Eng. Technol., 2011, 58, 588-593.

98. Jiang, H., Lu, L. and Sun, K., Experimental investigation of the impact of airborne dust deposition on the performance of solar photovoltaic (PV) modules. Atmos. Environ., 2011, 45(25), 42994304.

99. Adanu, K. (ed.), Performance of a $268 \mathrm{Wp}$ stand-alone PV system test facility. In Photovoltaic Energy Conversion, Conference Record of the 24th IEEE Photovoltaic Specialists Conference, 1994.

100. Bajpai, S. and Gupta, R., Performance of silicon solar-cells under hot and dusty environmental-conditions. Indian J. Pure Appl. Phys., 1988, 26(5), 364-369.

101. Kobayashi, S.-I. et al. (eds), Degradation of output characteristics of a small photovoltaic module due to dirt spots. 24th International IEEE Telecommunications Conference, 2005.
102. Zorrilla-Casanova, J. (eds), Analysis of dust losses in photovoltaic modules. In World Renewable Energy Congress, Sweden; 2011.

103. Massi Pavan, A., Mellit, A. and De Pieri, D., The effect of soiling on energy production for large-scale photovoltaic plants. Sol. Energ., 2011, 85(5), 1128-1136.

104. Mohamed, A. O. and Hasan, A., Effect of dust accumulation on performance of photovoltaic solar modules in Sahara environment. J. Basic Appl. Sci. Res., 2012, 2(11), 11030-11036.

105. He, G., Zhou, C. and Li, Z., Review of self-cleaning method for solar cell array. Proc. Eng., 2011, 16, 640-645.

106. Berg, R. S., Heliostat dust buildup and cleaning studies: Sandia Labs., Albuquerque, New Mexico, USA, 1978.

107. Mondal, A. K. and Bansal, K., A brief history and future aspects in automatic cleaning systems for solar photovoltaic panels. $A d v$. Robotics, 2015, 29(8), 515-524.

108. Mondal, A. K. and Bansal, K., Structural analysis of solar panel cleaning robotic arm. Curr. Sci., 2015, 108(6), 1047-1052.

109. Gaier, J. R., Perez-Davis, M. E. and Marabito, M. (eds), Aeolian removal of dust types from photovoltaic surfaces on Mars. In 16th Space Simulation Conference: Confirming Spaceworthiness into the Next Millennium, 1991.

110. Gaier, J. R. and Perez-Davis, M. E., Effect of particle size of Martian dust on the degradation of photovoltaic cell performance, 1991.

111. Hanaei, H., Assadi, M. K. and Saidur, R., Highly efficient antireflective and self-cleaning coatings that incorporate carbon nanotubes (CNTs) into solar cells: a review. Renew. Sust. Energy Rev., 2016, 59, 620-635.

112. Verma, L. K. et al., Self-cleaning and antireflective packaging glass for solar modules. Renew. Energy, 2011, 36(9), 24892493.

113. Morris, V. L., Cleaning agents and techniques for concentrating solar collectors. Sol. Energ. Mater.. 1980, 3(1-2), 35-55.

114. Mazumder, M., Sharma, R., Biris, A., Zhang, J., Calle, C. and Zahn, M., Self-cleaning transparent dust shields for protecting solar panels and other devices. Particul. Sci. Technol., 2007, 25(1), 5-20.

115. Sheratte, M., Cleaning agents and technologies for concentrating solar collectors. Tech Rep., Sandia Labs, Albuquerque, NM, USA, 1979, pp. 79.

116. www.solarpanelcleaningsystems.com/solar-panel-cleaning-services. php

117. www.serbot.ch/images/documents/TD_GEKKO $\% 20$ Solar $\% 20$ Farm En 2013 06 26.pdf

118. http://www.solarbrush.de/about

119. http://www.washpanel.com/en/documenti.php

120. http://www.greentechmedia.com/articles/read/SunPower-CleansUp-Solar-With-Acquisiton-of-Greenbotics

121. Piliougine, M. et al., Comparative analysis of energy produced by photovoltaic modules with anti-soiling coated surface in arid climates. Appl. Energ., 2013, 112, 626-34.

Received 26 December 2016; revised accepted 10 February 2018

doi: $10.18520 / \mathrm{cs} / \mathrm{v} 115 / \mathrm{i} 6 / 1065-1077$ 